\title{
Effects of water warming on bank filtration: experimental enclosure studies
}

\author{
A. Groß-Wittke, F. Selge \& G. Gunkel \\ Department of Water Quality Control, \\ Berlin University of Technology, Germany
}

\begin{abstract}
In the context of climate change artificial recharge of groundwater becomes increasingly important. The two main climate change factors affecting ground water recharge performance are water warming and extreme precipitation events with drought and floods. This will strongly influence self-purification processes, indirectly due to changes in the stratification and circulation characteristics of the lake and directly due to the intensification of metabolic processes and biodegradation efficiency, which are responsible for water self-purification.

At the study site Lake Tegel, Berlin (Germany), epilimnion water warming of $0.9^{\circ} \mathrm{C}$ per decade from 1980 to 2007 was detected. Moreover, continuous measurements of temperature for a yearly period from 2010 to 2011 in the openwater epilimnion and littoral zone showed a maximum difference of $5.2^{\circ} \mathrm{C}$ on a sunny summer day $\left(\mathrm{T}_{\text {Lake,max }}=25.3^{\circ} \mathrm{C}, \mathrm{T}_{\text {Air,max }}=26.2^{\circ} \mathrm{C}\right)$.

The present work describes the development and operation of enclosure field experiments conducted to simulate water warming (up to $30^{\circ} \mathrm{C}$ ) and to provide a detailed picture of the processes which occur in the uppermost sediment layers $(0-20 \mathrm{~cm}$ depth) at a littoral bank site. To illustrate the performance of the enclosure setup with a mean temperature increase of $4.6^{\circ} \mathrm{C}$ (May-August 2012), microbial activity as well as pore water analysis was examined monthly. Microbial activity was measured by enzymatic TTC- and FDA-methods. Both showed a highly microbial active upper layer down to 5 and $10 \mathrm{~cm}$ depth, respectively. However, no clear water warming effects on redox-chemical and microbial activity could be detected.

This paper is intended to contribute to an ongoing discussion, if in-situ enclosures enable realistic experimental studies to allow investigations of the
\end{abstract}


interactions between simulated climate warming and their impacts on biological structure and ecosystem processes.

Keywords: bank filtration, climate change, enclosure, groundwater recharge, microbial activity, water temperature.

\section{Introduction}

Significant water warming caused by climate change has been measured by many authors [1-5]. Empirical studies show that surface water temperature closely follows air temperature but it is also influenced by wind speed, humidity, cloud cover and clear-sky solar radiation as a predetermined variable [6, 7]. Long-term temperature monitoring studies are mainly performed in the centre of a lake [8], water of littoral zones under calm conditions are liable to stronger heating and cooling with an up- or downwelling of water. Particularly, shallow areas are highly relevant for bank filtration, because sediments are disaggregated by waves and meiofauna activities [9]. In contrast, deeper parts of a lake are often characterized as muddy with deposited organic material, which is slowly degradable under oxygen depression. Infiltration rates in organic rich sediments are not as high as in sandy littoral zones [10]. Littoral areas are significant for bank filtration although they are generally small compared to profundal lake area.

Artificial recharge of groundwater such as bank filtration as a sustainable method of saving groundwater resources has been of rising interest mainly for being an inexpensive and sustainable approach, especially in water stressed regions of the world. In Berlin, artificial recharge methods such as bank filtration and infiltration ponds are used to meet the drinking water demands of 3.4 mill. inhabitants. The water purification capacity during bank filtration depends on hydrogeological conditions such as properties of the aquifer and bank site, and operational practice [11] as well as on the surface water quality and quantity [12]. With special regard to climate change, temperature and precipitation are the two main climate change drivers affecting bank filtration. This will strongly influence self-purification processes, 1) due to changes in stratification and circulation characteristics of the lake and thus raw water quality and 2) due to the intensification of metabolic processes leading to a decrease in oxygen and an increase in anaerobic conditions with consequences for biodegradation efficiency. Increased temperatures are expected to stimulate bacterial growth rates [13] and lead to higher bacterial abundances [14]. Additionally, it seems likely that anoxic or anaerobic conditions will lead to increasing re-mobilisation of dissolved $\mathrm{Fe} / \mathrm{Mn}$ with rising temperature [1]. Moreover, some geochemical processes such as complexation, dissolution, degradation or evaporation will be favoured, whereas oxygen solubility decreases with rising water temperature.

For characterizing various dependent parameters and their effects on lake ecosystems, enclosures as model ecosystems were used [15]. In ecology, it is recognized that an observation of single environmental compartments is insufficient in providing an understanding of the whole system, so enclosure experiments were developed as an important additional tool to determine the 
complexity and interactions between parameters [16]. Manipulation of a whole lake system is expensive, very complex and in many countries prohibited. The observation of a relatively small volume has its advantages and drawbacks. Enclosure experiments, however, are controlled and repeatable at moderate costs. Examples which may be considered are the large-scale MELIMEX-enclosure, [17], Lund-enclosure [18] and enclosures by Schriver et al. [19]. Recently at Lake Stechlin, Germany, 24 sediment connected enclosures, each with over a volume of 1,200 $\mathrm{m}^{3}$ for research of climate change are in use. Furthermore, small enclosure experiments have been carried out many times worldwide for various purposes. Although this technique provides initial physiochemical and biological conditions in an experimental design, disadvantages due to isolation, size and other variables can occur. In particular, biological growth on the wall can lead to changes in chemical and biological reactions as well as to shadowing the inside of the enclosure. Reduced mixing caused by missing waves and wind fetch can influence water column stability [16]. Even though there are known rules for optimization and control, there is a controversy regarding the value of results achieved by enclosure experiments [16, 20-25].

There is still much to understand concerning the dynamics of underground purification processes, especially about temperature effects on hydro-chemical conditions and changes during the bank passage. This work aims to increase knowledge about this topic, by conducting enclosure field studies to simulate water warming and studying the influence of temperature increase (approx. $5^{\circ} \mathrm{C}$ ) on microbial activity as well as on redox processes, such as reduction of nitrate and sulphate. For these purposes, enzymatic activity and pore water were examined to detect fluctuations and changes in the concentrations of physicochemical parameters in the uppermost sediment layers (0-20 cm depth) at a bank filtration site, located at Lake Tegel in Berlin.

\section{Method and procedure}

\subsection{Study site}

Lake Tegel has an area of $2.82 \mathrm{~km}^{2}$, a water volume of around $15.42 \mathrm{mill} \mathrm{m}^{3}$, and a mean depth of $6.6 \mathrm{~m}$. Its maximum north east-south west longitudinal axis is around $2810 \mathrm{~m}$. The lake can be defined as a glacial enlargement of the river Havel. The lake's water quality is mesotrophic, but organic rich anoxic sediments are still typical, and cyanobacteria blooms occur periodically [26, 27].

At the shore of Lake Tegel, water abstraction for Berlin's water supply takes place through several galleries with 116 wells, the distance to the lake being about $100 \mathrm{~m}$. The range of calculated infiltration rates is between 0.05 and $3.6 \mathrm{~m} \mathrm{~d}^{-1}$. The daytime mean rate $\left(0.93 \mathrm{~m} \mathrm{~d}^{-1}\right)$ is double that during the night $\left(0.46 \mathrm{~m} \mathrm{~d}^{-1}\right)$, which is related to drinking water abstraction by local wells during the day. Experiments were conducted at the eastern shore of Lake Tegel, Berlin, Germany (N52³3’49.88'’ E1314’53.02” to N52³3’50.20’’ E13¹4’53.60”). 


\subsection{Constructional setup and operation}

The enclosures were constructed with transparent twin-wall sheets with side lengths of $1 \mathrm{~m} \times 1 \mathrm{~m}$ and $1 \mathrm{~m}$ in height for minimizing the wall effects. The single sheets were fixed airtightly together so that the air cushions reduced heat conductivity. The rectangular wall construction was pushed $20-30 \mathrm{~cm}$ into the sediment and strengthened with $2.5 \mathrm{~m}$ long steel squares at the in- and outside of the enclosure as shown in figure 1.

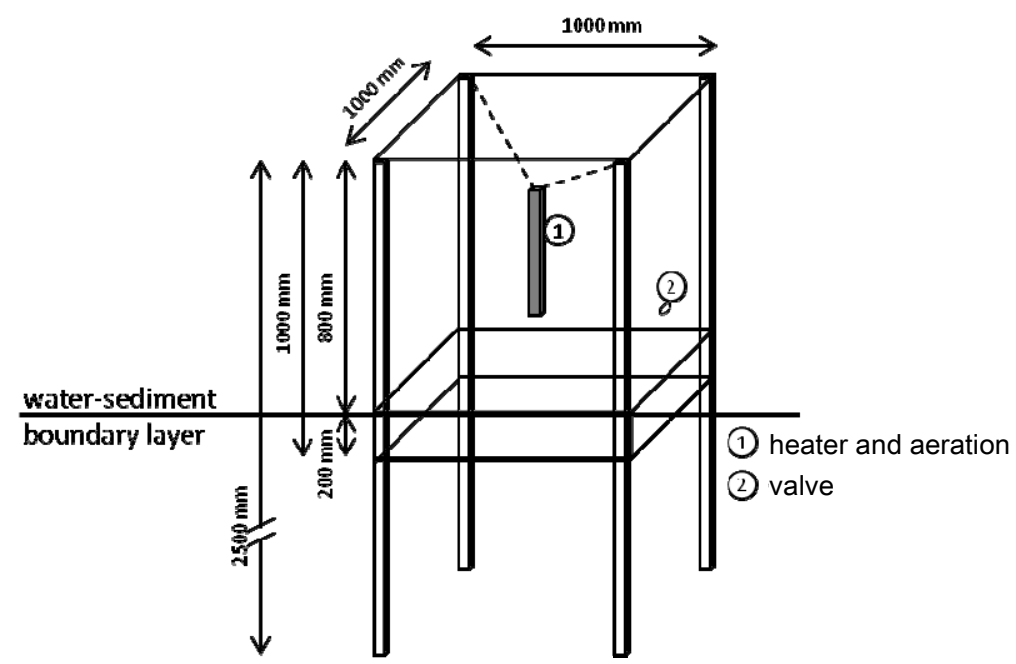

Figure 1: $\quad$ Schematic design drawing of the enclosure construction. The heater is an optional setting for increased water temperatures inside.

Within the wall of each enclosure a valve (JBL, 4/6 mm) was installed for water exchange with the lake and to regulate the water level.

Heating of water inside the enclosure was performed by direct heat input because of a simple setup. Therefore, a normal pond heater ( $300 \mathrm{~W}$; Schego, Germany) was installed vertically above the sediment and controlled by a timer. For constant and equal water temperature distribution within the water column and to provide slight water circulation, aquarium air pumps were installed. To avoid heavy input by external material such as leaves or falling branches, a coarse net covered the enclosure opening (figure 2).

Water level at the enclosure was around $0.5 \mathrm{~m}$. This leads to a ratio of depth to effective radius of approx. 1 , which is an indicator for minimized wall effects [16]. Nevertheless biofilm build up on the walls was prevented by regularly cleaning. The supply of air was also checked. 


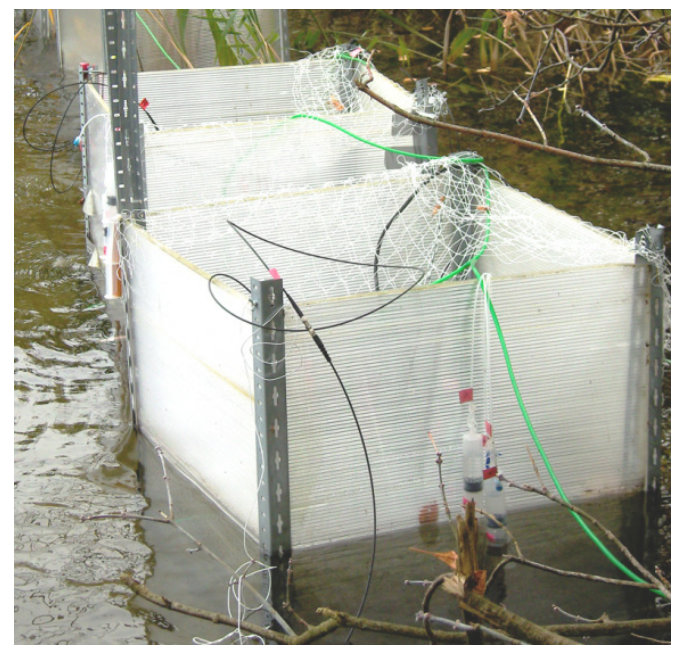

Figure 2: The enclosures at the bank filtration site, Lake Tegel, Berlin, Germany.

\subsection{Sampling}

In March 2012, two of these enclosures were installed at the bank filtration site, Lake Tegel. The enclosures were located in a row parallel to the bank line at about 2-3 $\mathrm{m}$ from the shore. One enclosure was heated (Encl), and one enclosure $\left(\right.$ Encl $\left._{\mathrm{ctrl}}\right)$ was kept at ambient lake water temperature. For detection of possible enclosure artifacts, one lake control site (Lake) was compared to the unheated enclosure. Furthermore, water temperature was measured every 10 min with submersible temperature data loggers (TinyTag Aquatic 2 TG-4100) around $10 \mathrm{~cm}$ above the sediment surface of the enclosures and the lake control site. In addition, pore water temperatures were recorded (10 min interval) at two different sediment depths $(5 \mathrm{~cm}$ and $30 \mathrm{~cm})$. For sampling of pore water, microsuction cups (UMS GmbH, München) equipped with a hydrophilic and porous polymer of $5 \mathrm{~cm}$ length and a filter pore size of $0.45 \mu \mathrm{m}$ were installed beneath the enclosures. Within each enclosure and at the lake control site, the suction cups were permanently inserted at three different sediment depths of 5,15 , and $30 \mathrm{~cm}$.

Pore water sampling was conducted monthly from March 2012. For sampling, a partial vacuum could be achieved by using of syringes $(60 \mathrm{ml})$ and a LuerLock system with Teflon tubes. Sediment core sampling from the enclosures and lake control by means of acrylic glass cylinders of length $50 \mathrm{~cm}$ and diameter 4.5 $\mathrm{cm}$ was conducted monthly during the study period. The sediment cores were transported to the laboratory and sliced into layers until $20 \mathrm{~cm}$ deep. The subsamples from each layer were subsequently analysed. 


\subsection{Analytical methods and analysis}

The present study applied two different enzymatic tests for the assessment of sediment microbial activity, through the analyses of dehydrogenase and esterase enzymes. Dehydrogensases and esterases are important enzyme groups for determining total microbial activities, because of their importance for microbial metabolism and the multitude of reactions they catalyse [28].

Dehydrogenases as respiratory chain enzymes play a major role in the energy production of organisms and thus fulfil a significant role in the oxidation of organic matter, by analysing this enzyme it is possible to detect metabolically active microorganisms and thus can be used as an indicator of biological redox systems and as a measure of microbial activity in soil $[28,29]$. Dehydrogenase activity can be measured using TTC (triphenyltetrazolium chloride) as artificial electron acceptors and was performed according to the German Standard DIN ISO 23753-1.

Many active extracellular enzymes retained in the biofilm system also contribute at a high level to the organic matter degradation. Esterases can be found extracellularly as well as intracellularly and are enzymes capable of cleaving ester-bonds. By measuring the conversion of FDA (3'6'-diacetylfluorescein) to fluorescein the general microbial decomposition activity can be determined and was performed according to Adam and Duncan [30].

Pore water and lake samples were filtered $(\varnothing 0.45 \mu \mathrm{m})$ and analysed immediately in the laboratory. Most parameters $\left(\mathrm{N}_{\text {total }}, \mathrm{NO}_{3}{ }^{-}\right.$, and $\left.\mathrm{NH}_{4}{ }^{+}\right)$were assayed by flow injection analysis (FIAstar 5000, Foss Tecator), while metal ion concentrations were determined by atomic absorption spectroscopy (Varian Spektra A 400). $\mathrm{Fe}^{2+}$ and $\mathrm{Mn}^{2+}$ were analysed using GBC 906A Scientific Equipment. $\mathrm{SO}_{4}{ }^{2-}$ was determined by ion chromatography (IC Dionex).

The development of surface water temperatures influenced by different weather variables at Lake Tegel was analysed for the period from 1980 to 2007 on a monthly data set.

\section{Results and discussion}

\subsection{In-situ climate change studies using enclosures}

\subsubsection{Development of enclosure}

The development of enclosures involves usually four steps. At first targets and hence requirements of the experiment have to be defined. Further, the design of the structure has to be settled, including material, stability, energy and costs. Next, installation and set up is important to implement the construction in the field without much disturbance to natural conditions. Finally this is followed by the execution of the experiment and maintenance of the construction.

\subsubsection{Requirements}

The main enclosure requirement is to provide a sufficient heating of the water for simulation of water warming. This is accompanied by heat output and thermal 
loss over the water, sediment and wall surface of the enclosure. Thermal loss is strongly related to heat conductivity, which limits the materials which can be used. Additionally, transparent materials are favoured because of the light regime inside the enclosure. For water warming, there are different possibilities, though each differs in energy supply and constructional set up. Due to climate variability, heating by solar energy could be insufficient. Another more flexible option is to have heat output from closed warm fluid circuits or energy input by direct heating. A watertight construction connected to sediments of a bank filtration site leads to a water level decrease over a longer period. On this account, water level compensation is necessary. Regarding the experimental setting, visibility and accessibility of the enclosure is an important factor, because outdoor experiments, especially in littoral areas may be frequently subjected to vandalism.

\subsubsection{Enclosure design}

The most important factor of heat loss is across the surface area, which is influenced by material choice, and can be calculated after Baehr and Stephan [31].

$$
\dot{Q}_{\text {out }}=k \cdot A \cdot d T
$$

$\dot{Q}_{\text {out }}=$ Heat $[\mathrm{J}] ; k=$ Heat conductivity $\left[\mathrm{J} \mathrm{kg}^{-1} \mathrm{~K}^{-1}\right] ; A=$ Surface area $\left[\mathrm{m}^{2}\right] ; d T=$ Temperature differences [K]

Convection by wind, eqn (2), and latent heat transfer, eqn (3), are calculable after Lerman et al. [32].

$$
\begin{aligned}
& \dot{Q}_{C}=f(u, . .) \cdot A \cdot\left(T_{W}-T_{A}\right) \\
& \dot{Q}_{E}=f^{*}(u, . .) \cdot A \cdot\left(e_{W}-e_{A}\right)
\end{aligned}
$$

$\dot{Q}_{\mathrm{C}}=$ Convective heat flow [W]; $\dot{Q}_{\mathrm{E}}=$ Latent heat flow [W]; $A=$ Water surface area; $T_{W, A}=$ Temperature of water, air; $e_{W, A}=$ Vapour pressure of water, air

Additionally, a bank filtration site with relative high infiltration rates shows also heat loss by warm water infiltration. In this case inflowing cold water has to be warmed continuously in the same way water infiltrates. This effect can be calculated after modifying Baehr and Stephan [31].

$$
\dot{Q}_{\text {inf }}=c_{p} \cdot I R \cdot \mathrm{A} \cdot d T
$$

$\dot{Q}_{\text {inf }}=$ Heat $[\mathrm{J}] ; \mathrm{c}_{\mathrm{p}}=$ Heat capacity of water $\left[\mathrm{J} \mathrm{kg}^{-1} \mathrm{~K}^{-1}\right] ; I R=$ Infiltration rate $\left[\mathrm{L} \mathrm{m}{ }^{-2} \mathrm{~h}^{-1}\right] ; A=$ Ground area of enclosure $\left[\mathrm{m}^{2}\right] ; d T=$ Temperature differences [K]

The sum of all thermal flows results in the total theoretical energy demand of the enclosure with a predefined temperature difference. In this way, feasibility of heating and costs are assessable. 
Not only thermal conditions are important for an enclosure design, but also the stability of the construction. There are two typical forces influencing the construction design. On the one hand, waves from wind and ships and on the other hand wind itself. Waves from shipping can have an especially high impact on stability due to their long wavelengths. The calculation of rectangular non breaking wave attack is best performed after the Sainflou method [33].

$$
\mathrm{p}=\gamma \cdot H \cdot\left(\cosh \frac{2 \cdot \pi \cdot \mathrm{d}}{\mathrm{L}}\right)^{-1}
$$

$\mathrm{p}_{1}=$ Pressure at the bottom of enclosure $\left[\mathrm{N} \mathrm{m}^{-2}\right] ; \gamma=$ Specific weight of water [N m$\left.{ }^{-3}\right] ; H=$ Wave height [m]; $d=$ Water depth [m]; $L=$ Wavelength [m]

To provide the necessary stability, the enclosure has to be anchored deeply enough into the sediment. The responsible parameter for stability is the friction between the enclosure and sediment, related to the buried surface area and their roughness. Our experience was that this parameter was underestimated.

\subsection{Modelling of Lake Tegel littoral water temperature}

By statistical multiple regression analyses after pre-selection of corresponding and independent variables, influence of air temperature, wind velocity, cloud cover and evaporation (calculated by Haude-model) on water temperature over the whole period was confirmed $\left(\mathrm{R}^{2}=0.84\right)$. After separation of weather and water data into seasonal periods, a shift in sensitivity of water temperature between four parameters is given. Multiple regression analyses show that wind velocity is the most important factor. In spring time, air temperature is dominating. Ambient air temperature is also dominant in summer and autumn followed closely by wind velocity. Evaporation has a decreasing effect on water temperature during spring and summer.

Continuous water temperature measurements show a daily and seasonal pattern of temperature differences between littoral and profundal zones. During a summer day (07.07.2011) with sunshine and low wind velocity, water temperature differences up to $4.2^{\circ} \mathrm{C}$ could be measured from early morning $(05: 30)$ to evening (18:50). In total, a water temperature difference could be registered of $4.7^{\circ} \mathrm{C}$ between open and littoral water. In the summer period, temperature differences show that the littoral has higher water temperatures than the open water in general. Although special events such as passing low-pressure systems with high cloud cover and wind velocities connected to low temperatures and rainfall are able to invert the spatial temperature distribution in the summer period. During the winter period, colder water temperatures in the littoral than in the lake profundal are common, but comparatively small.

\subsection{Experimental temperature stress in bank filtration}

\subsubsection{Enclosure water quality}

The heated enclosure with regulated heat input shows a mean temperature difference of about $4.6^{\circ} \mathrm{C}$ above ambient lake water (figure 3). 


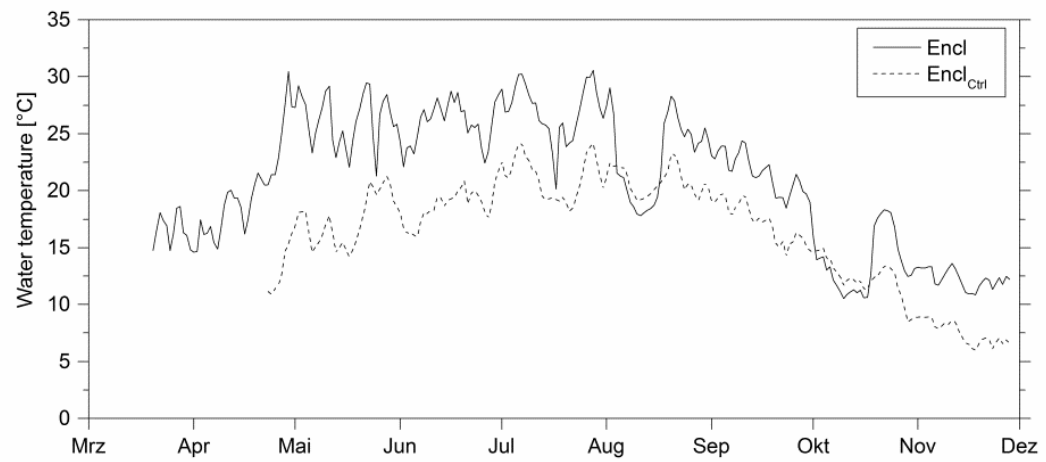

Figure 3: Daily mean water temperatures of the heated enclosure and ambient lake during field experiment. In August and October heating interrupted due to technical problems.

The seasonal water temperature pattern is followed by the heated enclosure at a higher water temperature. But on an hourly scale a shift of the daily pattern into the evening is significant. Water characteristics are listed in table 1.

Table 1: Surface water characteristics for the enclosures and the lake control.

\begin{tabular}{|l|c|l|c|l|c|l|}
\hline & Lake & $\begin{array}{l}\text { Standard } \\
\text { deviation }\end{array}$ & Encl & $\begin{array}{l}\text { Standard } \\
\text { deviation }\end{array}$ & Encl $_{\text {crrl }}$ & $\begin{array}{l}\text { Standard } \\
\text { deviation }\end{array}$ \\
\hline $\mathrm{NO}_{3}[\mathrm{mg} / \mathrm{L}]$ & 6.48 & \pm 4.32 & 1.26 & \pm 1.99 & 3.66 & \pm 4.08 \\
\hline $\mathrm{NH}_{4}[\mu \mathrm{g} / \mathrm{L}]$ & 23.42 & \pm 36.07 & 8.57 & \pm 17.13 & 29.59 & \pm 40.51 \\
\hline $\begin{array}{l}\text { Inorg. soluble } \\
{[\mathrm{mg} / \mathrm{L}]}\end{array}$ & 6.58 & \pm 4.43 & 1.30 & \pm 2.00 & 3.74 & \pm 4.09 \\
\hline $\mathrm{Fe}^{2+}[\mu \mathrm{g} / \mathrm{L}]$ & 112.93 & \pm 134.42 & 59.7 & \pm 43.76 & 32.4 & \pm 9.33 \\
\hline $\mathrm{Mn}^{2+}[\mu \mathrm{g} / \mathrm{L}]$ & 11.75 & \pm 5.99 & 30.03 & \pm 40.29 & 16.68 & \pm 16.26 \\
\hline $\mathrm{SO}_{4}[\mathrm{mg} / \mathrm{L}]$ & 104.3 & \pm 9.39 & 120.24 & \pm 20.01 & 99.29 & \pm 10.11 \\
\hline
\end{tabular}

Mean of the summer period (May-August 2012)

\subsubsection{Pore water quality}

Over the investigated period, the determined $\mathrm{N}_{\text {inorg }}$ concentration ranged between 36.99-0.06 mg L $\mathrm{mg}^{-1}$ (Lake), 13.37-0.36 mg L ${ }^{-1}$ (Encl), and 7.64-0.85 $\mathrm{mg} \mathrm{L}^{-1}$ $\left(\right.$ Encl $\left._{\text {ctrl }}\right)$. An overall tendency of decrease in $\mathrm{N}_{\text {inorg }}$ with time was recognizable mainly for the enclosures (figure 4), indicating bacterial denitrification within the interstices. For $\mathrm{Mn}^{2+}$ (figure 5), the highest concentrations in pore water were observed in April 2012 with the maxima of $200.0 \mu \mathrm{g} \mathrm{L}^{-1}$ (Lake), $270.0 \mu \mathrm{g} \mathrm{L}^{-1}$ (Encl), and $33.0 \mu \mathrm{g} \mathrm{L}^{-1}\left(\right.$ Encl $\left._{\mathrm{ctrl}}\right)$. From May until September, only traces of $\mathrm{Mn}^{2+}$ occurred within the pore water $\left(<6 \mu \mathrm{g} \mathrm{L}^{-1}\right)$ and surface water $\left(<100 \mu \mathrm{g} \mathrm{L}^{-1}\right)$, demonstrating the existence of further anoxic processes with a possible depletion of $\mathrm{Mn}^{4+}$ as alternative electron acceptor within the interstices. 


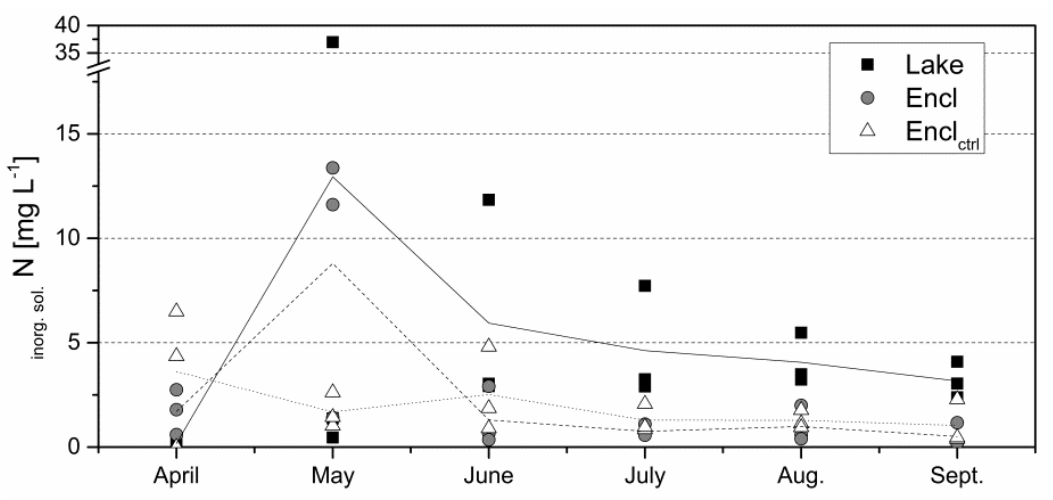

Figure 4: $\quad$ Pore water concentrations at sediment depths (5; 15; and $30 \mathrm{~cm}$ ), in 2012. Mean values are indicated as lines: solid (Lake), dashed (Encl), and points (Enclctrl).

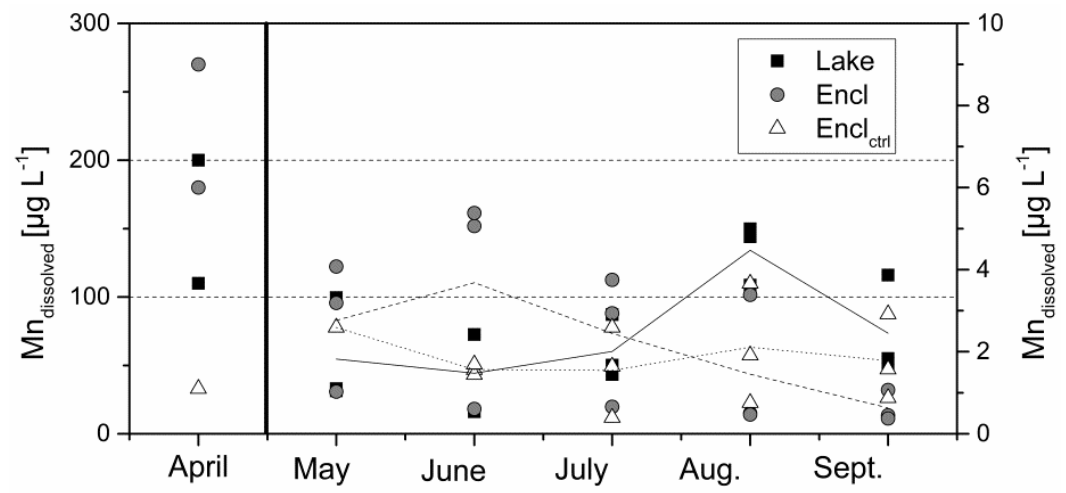

Figure 5: $\quad$ Pore water concentrations at sediment depths (5; 15; and $30 \mathrm{~cm}$ ), in 2012. Mean values are indicated as lines: solid (Lake), dashed (Encl), and points (Enclctrl); note that Mn-plotted with two y-axes.

Within pore water, measured $\mathrm{Fe}^{2+}$ concentrations were in the range of 813.0$3.0 \mu \mathrm{g} \mathrm{L}^{-1}$. A reduction of $\mathrm{Fe}^{3+}$ with a resulting re-mobilisation of $\mathrm{Fe}^{2+}$ within the interstice due to higher temperatures could not be observed for all sites (figure 6). 


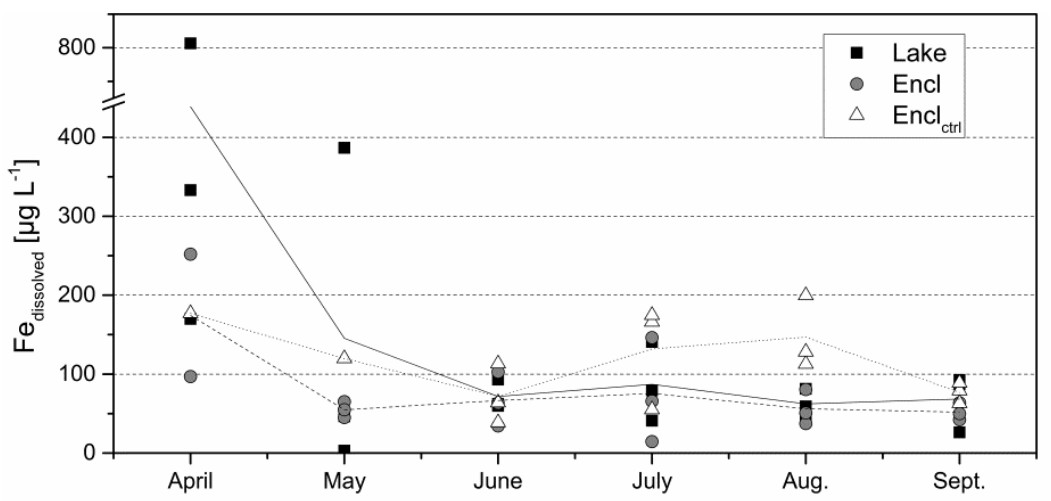

Figure 6: Pore water concentrations in sediment depths (5; 15; and $30 \mathrm{~cm}$ ), in 2012. Mean values are indicated as lines: solid (Lake), dashed (Encl), and points $\left(\right.$ Encl $\left._{\mathrm{ctrl}}\right)$.

The lower mean $\mathrm{Fe}^{2+}$ concentrations in the surface water of Encl $_{\mathrm{ctrl}}$ and Encl compared to the lake indicated chemical precipitation of iron, even though a high mean value variance exists (table1). Sulphate pore water values showed (figure 7) a slight increase with time, especially within the enclosures $\left(\right.$ Encl $_{\text {ctrl }}$ and Encl), thus no $\mathrm{SO}_{4}$ reduction with rising temperature could be detected. The $\mathrm{SO}_{4}$ concentration range for the lake site $\left(81.45-12.07 \mathrm{mg} \mathrm{L}^{-1}\right)$ even showed significantly ( $\alpha=0.05$ ) lower values compared to Encl ${ }_{\text {ctrl }}\left(106.77-64.80 \mathrm{mg} \mathrm{L}^{-1}\right)$, and Encl (108.43-46.44 $\mathrm{mg} \mathrm{L}^{-1}$ ).

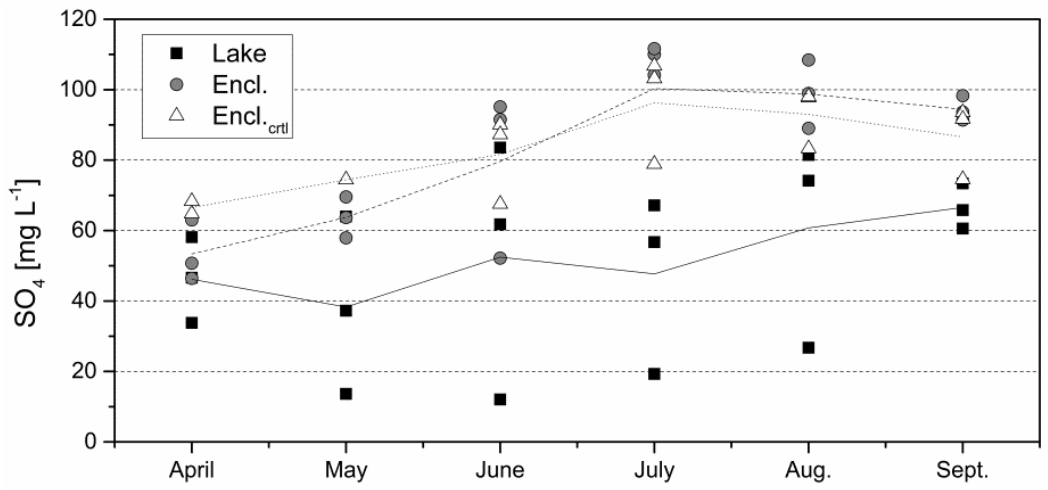

Figure 7: $\quad$ Pore water concentrations in sediment depths (5; 15; and $30 \mathrm{~cm}$ ), in 2012. Mean values are indicated as lines: solid (Lake), dashed (Encl), and points ( Encl $\left._{\mathrm{ctrl}}\right)$.

On the basis of the pore water results for all sites, the redox state along the pathway is described by microbial denitrification and $\mathrm{Mn}^{4+}$-reduction, while the reduction of $\mathrm{Fe}^{3+}$ and $\mathrm{SO}_{4}$ is unincisive. This is consistent with several studies 
where denitrification rates are strongly influenced by seasonal/ annual temperature variations [34-36]. However, we detected very little response of redox-sensitive species such like $\mathrm{Mn}^{2+} / \mathrm{Fe}^{2+}$, and $\mathrm{SO}_{4}$ in pore water to higher temperatures (Encl). This is in contrast with findings of intensification of redox reactions leading to the development of negative redox potentials and the increase in more anaerobic /anoxic processes with rising water temperature [1].

\subsubsection{Microbial activity}

The results of microbial activity as enzyme activity of dehydrogenase (TTC) are presented here exemplary for the summer period 2012 (May-August) enclosures $\left(\right.$ Encl $_{\mathrm{ctrl}} /$ Encl.) and lake control plot dehydrogenase activity measured in $0-15 \mathrm{~cm}$ depth of the sediment are given in figure 8 .

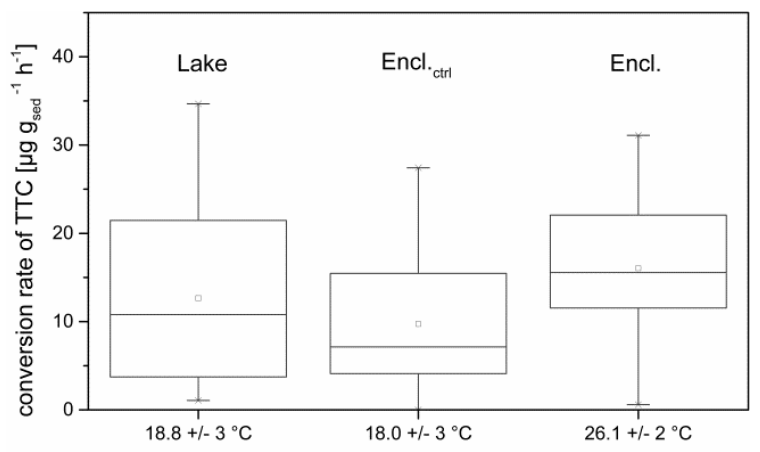

Figure 8: Box-plot of the conversion rate of TTC by dehydrogenase at mean water temperature over the period May-August 2012.

The mean water temperature of the heated enclosure is, with $26.1+/-2^{\circ} \mathrm{C}$, up to $8^{\circ} \mathrm{C}$ higher than in the unheated enclosure $\left(18.0+/-3^{\circ} \mathrm{C}\right)$ and the lake control $\left(18.8+/-3^{\circ} \mathrm{C}\right)$. However, during the summer period from May until August 2012, the determined microbial activity values are within the same range for all investigated sites and thus no clear impact of water temperature rise on the intensity of esterase/dehydrogenase activity could be registered by both methods. Moreover, no statistically significant distinction between the measured esterase/dehydrogenase activity at the different enclosures and the lake control for the whole summer period could be proven (figure 8).

The low enzymatic activity within the heated (Encl) and unheated (Encl $\left.\mathrm{ctrl}_{1}\right)$ enclosures, indicating more complex dependencies of microbial activity on temperature and other influencing factors e.g. C-limitation, seasonality, and community structure of the microbes.

However, the lack of warming effects on redox-chemical conditions as well on microbial activity is contrary to expectations and may point out that the mean water temperature difference of around $5^{\circ} \mathrm{C}$ between the lake and the heated enclosure is insufficient to induce warming effects on bank filtration performance. Thus, continuing investigations should apply higher temperature differences, even at the risk of inducing the collapse of the system. Other studies 
on bank filtration in tropical and sub-tropical countries showed that purification during infiltration still works at higher temperatures of up to $35^{\circ} \mathrm{C}[37,38]$. Additionally, more replicates are recommended to reduce the variability/patchiness between the enclosures and the development of unknown artefacts.

The difference in temperature is unlikely to fully explain the results. Further field studies/investigations are essential, especially concerning other seasonal variations such as community structure of the microbes or nutrition loads, and availability of carbon sources has to be taken into account.

\section{Conclusion}

Climate change influences on fresh water ecosystems are highly significant and have become a focus of further research activities all over the world. Within this context, enclosure field experiments to simulate climate warming were developed and applied at the bank filtration site at Lake Tegel, Germany. As a result, the experimental setup could achieve a mean temperature increase of $4.6^{\circ} \mathrm{C}$ within the heated enclosure during the whole study period. This indicates that the construction and operation of the enclosures has been confirmed as an easy and simple method to simulate water warming. Moreover, the input of oxygen due to aeration of the surface water should be considered as critical. The main results are:

- denitrification processes such as microbial catalysed $\mathrm{NO}_{3}^{-}$reduction and $\mathrm{Mn}^{4+}$-reduction after the consumption of oxygen were recognizable at all sites.

- mean water temperature rise of $4.6^{\circ} \mathrm{C}$ could be achieved at the heated enclosure for the whole study period.

- Distinct water warming effects on redox-chemical processes and microbial activity could not be detected.

\section{Acknowledgements}

The authors would like to thank Mr. R. Hatton for his help in preparing this manuscript and also the Berliner Wasserbetriebe (BWB) for cooperation and providing a sheltered position for the experimental setup.

\section{References}

[1] Groß-Wittke, A., Gunkel, G. and Hoffmann, A., Temperature effects on bank filtration: redox conditions and physical-chemical parameters of pore water at Lake Tegel, Berlin-Germany, Journal of Water and Climate Change, 1(1), pp. 55-66, 2010.

[2] Meis, S., Thackeray, S.J. and Jones, I.D., Effects of climate change on phytoplankton phenology in a temperate lake, Freshwater Biology, 54(9), pp. 1888-1898, 2009. 
[3] Livingstone, D.M., A Change of Climate Provokes a Change of Paradigm: Taking Leave of Two Tacit Assumptions about Physical Lake Forcing, International Review of Hydrobiology, 93, pp. 404-414, 2008.

[4] Vollmer, M.K., Bootsma, H.A., Hecky, R.E., Patterson, G., Halfman, J.D., Edmond, J.M., Eccles, D.H. and Weiss, R.F., Deep-Water Warming Trend in Lake Malawi, East Africa, Limnology and Oceanography, 50(2), pp. 727-732, 2005.

[5] Magnuson, J.J., Webster, K.E, Assel, R.A., Bowser, C.J., Dillon, P.J., Eaton, J.G., Evans, H.E., Fee, E.J., Hall, R.I., Mortsch, L.R., Schindler, D.W. and Quinn, F.H., Potential effects of climate changes on aquatic system: Laurentian Great Lakes and precambrian shield region, Hydrological Processes, 11, pp. 825-871, 1997.

[6] Livingstone, D.M. and Imboden D.M., Annual heat balance and equilibrium temperature of Lake Aegeri, Switzerland, Aquatic Sciences, 51(4), pp. 351-369, 1989.

[7] Wilhelm, S., Hintze, T., Livingstone, D.M. and Adrian, R., Long-term response of daily epilimnetic temperature extrema to climate forcing, Canadian Journal of Fisheries and Aquatic Sciences, 63, pp. 2467-2477, 2006.

[8] Horsch, G.M. and Stefan, H.G., Convective circulation in littoral water due to surface cooling, Limnology and Oceanography, 33(5), pp. 1068-1083, 1988.

[9] Hoffman, A. and Gunkel, G., Bank filtration in the sandy littoral zone of Lake Tegel (Berlin): Structure and dynamics of the biological active filter zone and clogging processes, Limnologica, 41(1), pp. 19-19, 2011.

[10] Massmann, G., Nogeitzig, A., Taute, T. and Pekdeger, A., Seasonal and spatial distribution of redox zones during lake bank filtration in Berlin, Germany, Environmental Geology, 54, pp. 53-65, 2008.

[11] Grischek, T., Schoenheinz, D., Ray, C., Siting and Design Issues for Riverbed Filtration Shemes (Chapter 14). Riverbank Filtration, ed. C. Ray, G. Melin, R. Linsky, Kluwer Academic Publishers: New York, Boston, Dordrecht, London, Moscow, pp. 291-302, 2003.

[12] Stuyfzand, PJ., Hydrology and water quality aspects of rhine bank groundwater in The Netherlands. Journal of Hydrology, 106, pp. 341-363, 1989.

[13] Edward R., T., and Meyer,J. L., Production and turnover of planktonic bacteria in two southeastern blackwater rivers. Applied and Environmental Microbiology, 52, pp. 1317-1323, 1986.

[14] Lamberti, G., A. and Resh, V., H., Geothermal effects on stream benthos: Separate influences of thermal and chemical components on periphyton and macroinvertebrates. Canadian Journal of Fisheries and Aquatic Science, 40, pp.1995-2009, 1983.

[15] Bloesch, J., Mesocosm studies, Hydrobiologica, 159, pp. 221-222, 1988.

[16] Petersen, J.E., Kennedy, V.S., Dennison, W.C.and Kemp, W.M., Enclosed Experimental Ecosystems and Scale, Springer-Verlag, New York, pp. 221, 2009. 
[17] Bossard, P. and Gächter, R., MELIMEX, an experimental heavy metal pollution study: Effects of increased heavy metal load on uptake of glucose by natural planctonic communities, Schweizerische Zeitschrift für Hydrologie, 41(2), pp. 261-270, 1979.

[18] Lundgren, A., Model ecosystems as a tool in freshwater and marine research, Archiv für Hydrobiologie, 70, pp. 157-196, 1985.

[19] Schriver, P., Bøgestrand, J., Jeppesen, E. and Søndergaard, M., Impcat of submerged macrophytes on fish-zooplankton-phytoplankton interactions: large-scale enclosure experiments in a shallow eutrophic lake, Freshwater Biology, 33, pp. 255-270, 1995.

[20] Schrader, K.K., Tucker, C.S., De Regt, M.Q. and Kingsbury, S.K., Evaluation of Limnocorrals for Studying the Effects of Phytotoxic Compunds on Plankton and Water Chemistry in Aquaculture Ponds, Journal of the World Aquaculture Society, 31(3), pp. 403-415, 2000.

[21] Carpenter, S.R., Chisholm, S.W., Krebs, C.J., Schindler, D.W., Wright, R.F., Ecosystem Experiments, Science, 269(5222), pp. 324-237, 1995.

[22] Carpenter, S.R., Microcosm Experiments have Limited Relevance for Community and Ecosystem Ecology, Ecology, 77(3), pp. 677-680, 1996.

[23] Mazumder, A., Taylor, W.D., McQueen, D.C., Lean, D.R.S. and Lafontaine, N.R., A comparison of lakes and lake enclosures with contrasting abundances of plankivorous fish, Journal of Plankton Research, 12(1), pp. 109-124, 1990.

[24] French, R.H. and Watts, R.J., Performance of in situ microcosms compared to actual reservoir behavior, Journal of Environmental Engineering, 115, pp. 835-849, 1989.

[25] Bloesch, J., Bossard, P. , Bührer, H., Biirgi, H. R. and Uehlinger, U., Can results from limnocorral experiments be transferred to in situ conditions?, Hydrobiologia,159,, pp. 297-308, 1988.

[26] Heinzmann, B., Chorus, I., Restoration concept for Lake Tegel, a major drinking and bathing water resource in a densely populated area, Environmental Science and Technology, 28, pp. 1410-1416, 1994.

[27] Schauser, I., Chorus, I., Heinzmann, B., Strategy and current status of combating eutrophication in two Berlin lakes for safeguarding drinking water resources. Water Science and Technology, 54, pp. 93-100, 2006.

[28] Gumprecht, R., Gerlach, H., Nehrkom, A., FDA hydrolysis and resazurin reduction as a measure of microbial activity in sediments from the southeast Atlantic. Helgoland Marine Research, 49(1-4), pp. 189-199, 1995.

[29] Griebe, T., Schaule, G., Wuertz, S., Determination of microbial respiratory and redox activity inactivated sludge. Journal of Industrial Microbiology \& Biotechnology, 19, 118-122, 1997.

[30] Adam, G. and Duncan, H., Development of a sensitive and rapid method for the measurement of total microbial activity using fluorescein diacetate (FDA) in a range of soils. Soil Biology \& Biochemistry, 33, 943-951, 2001.

[31] Baehr, H.D. and Stephan, K., Wärme- und Stoffübertragung. 5th edition Springer-Verlag, Berlin Heidelberg New York, pp. 34-38, 2006. 
[32] Lerman, A., Imboden, D. and Gat, J., Physics and Chemistry of Lakes, Second Edition, Springer-Verlag, Berlin Heidelberg New York, pp. 63-74, 83-138, 1995.

[33] EAU (Empfehlungen des Arbeitsausschusses „Ufereinfassungen“), Empfehlungen des Arbeitsausschusses „Ufereinfassungen“ Häfen und Wasserstraßen. Ernst \& Sohn, Berlin, pp. 137-139, 2004.

[34] Carrera, J., Vicent, T. and Lafuente, F.J., Influence of temperature on dentrification of industrial high-strength nitrogen wastewater in a twosludge system. Water SA. 29 (1), pp. 11-16, 2003.

[35] Kamp-Nielsen, L. and Kongshoj, N., Temperature models for nitrification and denitrification in lake sediments, Verhandlungen des Internationalen Vereins Limnologie, 30(9), p. 1384-1388, 2010.

[36] Song, K., Seung-Hoon, L., Hojeong, K., Dentrification rates and community structure of denitrifying bacteria in newly constructed wetland, European Journal of Soil Biology, 47, pp. 24-29, 2011.

[37] Lorenzen, G., Sprenger, C., Taute, T., Pekdeger, A., Mittal, A. and Massmann, G., Assessment of potential for bank filtration in a water stressed magacity (Delhi, India), Environmental Earth Science, 61, pp. 1419-1434, 2010.

[38] Freitas, D. A., Cabral, J. J. S. P., Palva, A. L. R. and Molica, R. J. R., Application of bank filtration technology for water quality improvement in a warm climate: a case study at Beberibe River in Brazil. Journal of Water Supply, 61.5, pp. 319-330, 2012. 